\title{
USP28 Gene
}

National Cancer Institute

\section{Source}

National Cancer Institute. USP28 Gene. NCI Thesaurus. Code C124089.

This gene plays a role in both protein deubiquitination and DNA damage responses. 